\title{
PERSEPSI MAHASISWA BIOLOGI TERHADAP PERKULIAHAN DARING SEBAGAI SARANA PEMBELAJARAN SELAMA PANDEMI COVID-19
}

\author{
Sidatul Maulah ${ }^{1}$, Farikhatun Nurul A ${ }^{1}$, Nofida R. Ummah ${ }^{1}$ \\ ${ }^{1}$ Institut Agama Islam Negeri Jember, Jl. Mataram No. 1 Mangli, Jember 68136, \\ Jawa Timur, Indonesia \\ E-mail: $\underline{\text { sidamaulah25@gmail.com }}$
}

\begin{abstract}
With the absence of the COVID-19 universities in Jember Regency to perform lectures online or online. In the implementation of his studies, different from conventional lectures so that the use of learning Model determine the effectiveness of the lecture at the time of the COVID-19. This study examines the student perception of biology Model learning through the approach of using learning media in Atrevido lectures, Model learning communication, learning style, and the effectiveness of online lectures. The method used in this study is a descriptive analysis. The number of research samples as much as 50 college student with online poll with the population of the campus in Jember district include IAIN Jember, IKIP Jember, UNMUH Jember, UNEJ, UIJ which has been implementing the DAR during the 19 Carantinan. From online poll filling students prefer WhatsApp application as effective learning media with a percentage of (47\%), Model Communication semi-directional (70\%), visual learning style with a percentage (64\%), and with the presence of online lectures this student biology is still less satisfied about what is received during the course of online, because there is a related faitor that makes feel less. This can be solved by choosing the right learning Model.
\end{abstract}

Keywords: Perception, COVID-19, learning model, online lectures

\begin{abstract}
Abstrak: Dengan adanya pendemi COVID-19 Perguruan Tinggi yang ada di Kabupaten Jember melaksanakan perkuliahan secara daring atau online. Dalam pelaksanaan pembelajarannya, berbeda dengan perkuliahan konvensional sehingga penggunaan model pembelajaran menentukan keefektifan perkuliahan daring pada masa COVID-19. Penelitian ini mengkaji persepsi mahasiswa Biologi model pembelajaran melalui pendekatan penggunaan media pembelajaran dalam perkuliahan daring, model komunikasi pembelajaran, gaya belajar, dan keefektifan perkuliahan daring. Metode yang digunakan dalam penelitian ini ada-lah analisis deskriptif. Jumlah sampel penelitian sebanyak 50 mahasiswa dengan pemberian angket secara online dengan populasi kampus yang ada di Kabupaten Jember meliputi IAIN Jember, IKIP Jember, UNMUH Jember, UNEJ, UIJ yang sudah melaksanakan daring selama karantina COVID-19. Dari pengisian angket online mahasiswa lebih menyukai aplikasi whatsapp sebagai media pembelajaran yang efektif dengan presentase sebanyak (47\%), model komunikasi semi dua arah (70\%), gaya belajar visual dengan presentase (64\%), dan dengan adanya perkuliahan daring ini mahasiswa Biologi masih kurang puas atas apa yang diterima selama perkuliahan daring, karena ada berbagai faktor yang membuat merasa kurang puas. Hal ini, dapat diatasi dengan memilih model pembelajaran yang tepat.
\end{abstract}

Kata kunci: Persepsi, COVID-19, model pembelajaran, perkuliahan daring

Pendidikan mempunyai arti usaha sadar untuk menyiapkan peserta didik melalui kegiatan bimbingan, pengajaran, dan latihan bagi peranannya dimasa yang akan datang. Menyadari pentingnya pendidikan, Pemerintahan merumuskan Tujuan Pendidikan Nasional dalam Undang-undang No 2 Tahun 1989. Pembelajaran merupakan hal utama dalam pendidi- 
kan yang pelaksanaannya secara terus menerus. Seiring bertambahnya angka pasien positif COVID-19 di Indonesia, Pemerintah melalui Kemendikbud menerbitkan Surat Edaran Nomor 3 Tahun 2020 tentang Pencegahan COVID-19 pada satuan Pendidikan. Program belajar dari rumah ini telah diterapkan dari berbagai tingkatan pendidikan di Indonesia, tak terkecuali di tingkat perguruan tinggi (Kemendikbud, 2020). Menindaklanjuti anjuran Kemendikbud tentang rambu-rambu pelaksanaan kegiatan akademik dalam masa darurat, para Rektor Perguruan Tinggi yang ada di Kabupatem Jember meniadakan kegiatan pembelajaran konvensional dan menggantinya dengan pembelajaran daring. Pembelajaran daring merupakan kebijakan nasional sebagai langkah strategis dalam upaya pencegahan penyebaran virus COVID-19. Dengan adanya himbauan tersebut maka peroses pembelajaran dilaksanakan dari rumah dengan memanfaatkan teknologi dan media internet secara synchronous atau asynchronous. Perkembangan teknologi informasi komunikasi di era 4.0 yang pesat memudahkan dalam keberlangsungan perkuliahan daring. Media sosial sebagai media daring yang memudahkan para penggunanya berkomunikasi antarmuka, berpartisipasi, dan berbagi. Dan bagi dosen adanya pembelajaran daring ini merupakan pengubahan pembelajaran dengan metode tradisional menjadi pembelajaran online atau kuliah online yang secara tidak langsung menguji keprofesionalitasan dosen dalam mengajar.

Mengamati efektifitas pembelajaran daring dari segi pandang Mahasiswa Biologi di Perguruan Tinggi Kabupaten Jember. Pembelajaran daring mempunyai teknis yang berbeda dari model pembelajaran system tatap muka yang dilakukan dengan pembelajaran full online serta memudahkan pelaksanaannya untuk mengakses dimana saja. Hal ini mengandalkan internet sebagai laju perkuliahan. Tidak hanya itu, perkuliahan daring juga memudahkan para dosen dan mahasiswa dalam menentukan model komunikasi untuk pelaksanaan pembelajaran. Pembelajaran terwujud dalam bentuk interaksi secara timbal balik yang dinamis antara mahasiswa dengan dosen dalam kondisi belajarnya.Yang mana pola interaksi dibagi menjadi tiga yaitu interaksi satu arah, dua arah dan semi dua arah.

Kegiatan perkuliahan daring yang berlangsung secara real time membuat pendidik memilih aplikasi yang tepat untuk keberlangsungan pembelajaran. Dalam hal ini, beberapa perguruan tinggi menggunakan kebijakan dalam penggunaan aplikasi yang bersifat distingtif (LMS dan sister). Dan menggunakan berbagai aplikasi yang bersifat universal seperti Zoom, Edmodo, Whattsapp (WA), Youtube (Ytb), Flickr (Flc), Instagram (Ins), Twitter (Twt), Webblog (Wbg), dan Linkedln (Lin) (Kuntarto \& Asyhar, 2017). Umumnya mahasiswa beranggapan aplikasi yang mudah dalam pengoperasiannya dan hemat kuota efektif dalam menunjang pembelajaran daring. 
Namun dalam pelaksanaannya tidak menutup kemungkinan terjadi kendala, permasalahan dan daya dukung pembelajaran daring di rumah yang dialami para mahasiswa membuat pembelajaran tidak efektif. Permasalahan yang terjadi meliputi minimnya jaringan, ketersediaan perangkat pembelajaran (salah satunya laptop), suasana rumah dan lingkungan sekitar yang tidak mendukung juga turut menentukan efektifitas pembelajaran daring. Kesulitan terbesar yang dialami mahasiswa yaitu tingkat pemahaman materi, karena gaya belajar pada masing-masing mahasiswa mempengaruhi tingkat pemahaman dalam penyerapan materi pembelajaran. Dan fakta empiris menurut Tuncay, dkk, (2011) menyebutkan bahwa pembelajaran full online dianggap kurang dapat mengakomodasi seluruh kebutuhan pembelajaran.

Penelitian ini dikhususkan bagi mahasiswa Biologi yang pembelajarannya tidak hanya sebatas penyampaian materi saja namun perlu dilakukan penelitian seperti pelaksanaan praktikum baik di laboratorium maupun lapangan. Seiring proses pembelajaran daring, beberapa materi yang harusnya dilaksanakan penelitian terpaksa tidak dilaksanakan. Dengan adanya kendala tersebut persepsi mahasiswa mengenai efektifitas perkuliahan daring yang mengarah pada model pembelajaran dengan pendekatan media pembelajaran, model komunikasi, gaya belajar dikalangan mahasiswa Biologi di Kabupaten Jember menentukan keberhasilan proses pembelajaran ini. Dengan ini peneliti mengkaji persepsi mahasiswa Biologi terhadap perkuliahan daring selama pandemi COVID-19 sebagai sarana pembelajaran di Kabupaten Jember.

\section{METODE}

Penelitian kali ini menggunakan Analisis Deskriptif yaitu untuk mengkaji presepsi mahasiswa Biologi mengenai model pembelajaran daring selama pandemik COVID-19 di Kabupaten Jember. Yang mana model pembelajaran daring tersebut dapat diketahui melalui beberapa pendekatan, seperti media pembelajaran daring, model komunikasi pembelajaran, gaya belajar dan efektivitas pembelajaran daring. Data diperoleh dari hasil observasi dalam bentuk pemberian angket online. Sampel yang terlibat yaitu mahasiswa Biologi dari lima perguruan tinggi yang ada di Kabupaten Jember anatara lain IAIN Jember, Universitas Negeri Jember, IKIP Jember, Universitas Islam jember, dan Universitas Negeri Muhammadiyah Jember sebagai responden dalam penelitian ini. Penentuan responden sebagai sample dilakukan dengan metode probability dengan pendekatan stratified random sampling. Dalam penelitian ini terdapat 50 responden sebagai sample dari mahasiswa Biologi yang tersebar di Perguruan Tinggi Kabupaten Jember. 


\section{HASIL}

Berikut adalah hasil dari presentase persepsi mahasiswa Biologi terhadap perkuliahan daring sebagai penunjang pembelajaran di masa pandemi COVID-19 :

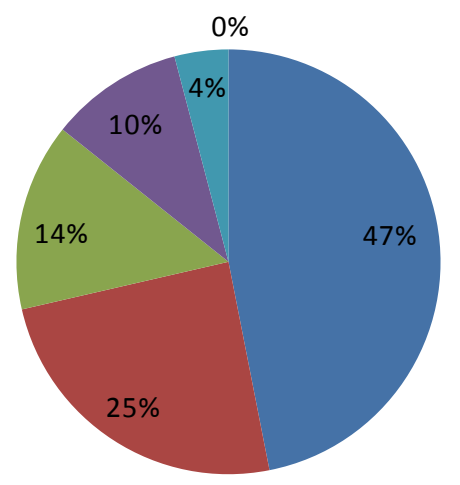

$$
\begin{aligned}
& \text { Whats app } \\
& \text { Gogle Clasroom } \\
& \text { zoom/webex/Gm } \\
& \text { - Lms/sister } \\
& \text { Edmodo } \\
& \text { Telegram }
\end{aligned}
$$

\section{Gambar 1. Presentase Mengenai Keefektifan Media Pembelajaran Daring}

Diagram lingkaran di atas menunjukkan keefektifan media pembelajaran daring selama pandemi COVID-19. Dari penggunaan media pembelajaran, mahasiswa lebih menyukai penggunaan aplikasi WhatsApp dengan presentase 47\%, 25\% memilih Google Classroom, 14\% memilih aplikasi video converence seperti Zoom, Google meet, Webex , Serta 10\% memilih E-learning yang disediakan dari kampus, 4\% memilih Edmodo, dan yang memilih, dan $0 \%$ yang memilih Telegram. Dengan pemilihan aplikasi yang efektif memudahkan mahasiswa dan dosen dalam menuntukan model komunikasi.

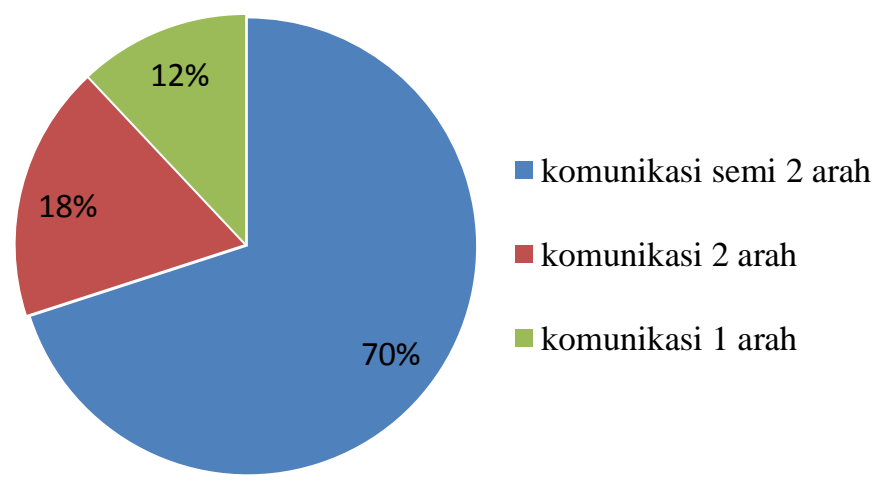

\section{Gambar 2. Persepsi Model Komunikasi Dalam Pembelajaran}

Diagram lingkaran di atas menunjukkan jenis model komunikasi dalam pembelajaran yang disukai oleh mahasiswa Biologi selama masa pandemi COVID-19. Model komunikasi ini menentukan cara interaksi dalam pembelajaran daring antara mahasiswa dengan dosen. Terkadang interaksi dalam pembelajaran daring terdapat interaksi secara timbal balik antara dosen dan mahasiswa dan ada juga yang mengkhususkan dosen saja yang menyalurkan infor- 
masi sedangkan mahasiswa sebagai penerima informasi tidak dapat memberikan umpan balik. Hasil persepsi di atas menunjukkan $70 \%$ mahasiswa memilih komunikasi semi dua arah, 18\% memilih komunikasi dua arah dan 12\% memilih satu arah dalam menunjang efek-tifitas perkuliahan.

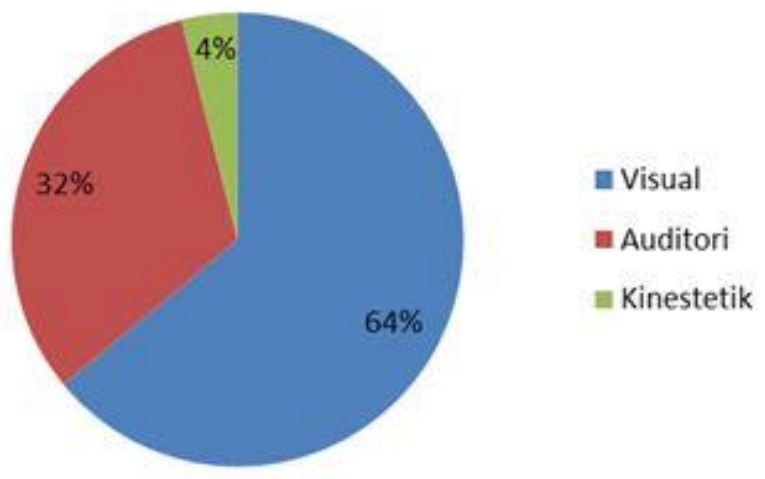

\section{Gambar 3. Persepsi Gaya Belajar}

Diagram lingkaran diatas menunjukkan gaya belajar mahasiswa Biologi selama pandemi COVID-19. Gaya belajar merupakan pemahaman individu dalam mencerna materi pembelajaran, yang mana setiap mahasiswa mempunyai gaya belajar sendiri-sendiri. Dengan ini para dosen tidak hanya memberikan materi berupa teks namun diperlukan materi berupa video atau audio sebagai penunjang materi mahasiswa. Hasil presentase menunjukkan bahwa $64 \%$ mahasiswa memilih gaya belajar visual, $32 \%$ mahasiswa memilih auditori, dan sisanya $4 \%$ memilih kinestetik.

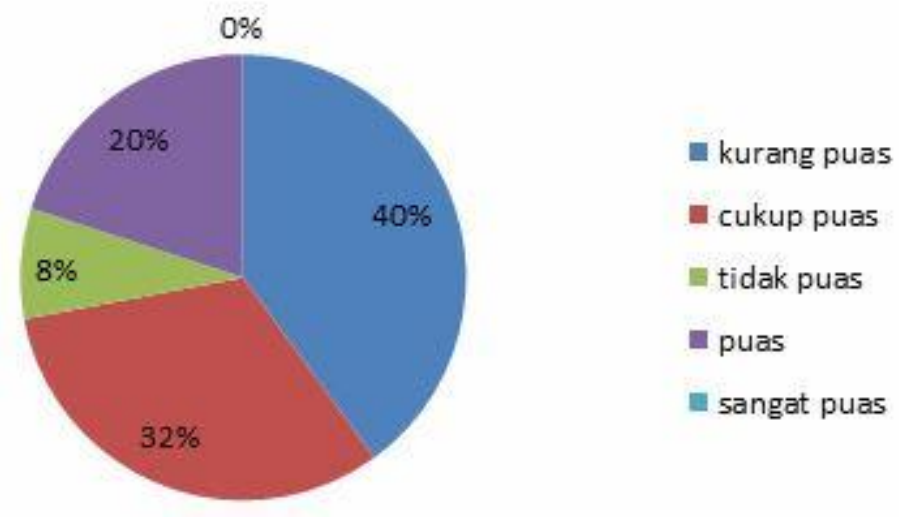

Gambar 4. Efektifitas Perkuliahan Daring

Diagram lingkaran diatas menunjukkan presentase efektifitas perkuliahan daring bagi Mahasiswa Biologi di Perguruan Tinggi Kabupaten Jember. Hasil presentase menunjukkan $40 \%$ mahasiswa kurang puas, $32 \%$ merasa cukup puas, $20 \%$ merasa puas, $8 \%$ merasa tidak puas, dan $0 \%$ mahasiswa merasa sangat tidak puas. 
Efektifitas perkuliahan daring dipengaruhi oleh model pembelajaran dengan beberapa pendekatan seperti media pembelajaran, model komunikasi dan gaya belajar yang tepat. Dengan pemilihan model pembelajaran yang tepat membuat perkuliah daring berjalan dengan lancar dan efektif.

\section{PEMBAHASAN}

Penelitian ini merupakan bagian dari penelitian model pembelajaran daring mahasiswa Biologi di Perguruan Tinggi Kabupaten Jember. Berdasarkan hasil dari penelitian yang diperoleh observasi angket online dapat mendeskripsikan mahasiswa Biologi di Perguruan Tinggi Kabupaten Jember.

Proses belajar mengajar yang diteliti yaitu pembelajran daring yang mana telah di lakukan dalam rangkan pemutusan rantai COVID-19, terdapat pada surat edaran yang diterbitkan Mendikbud Nomor 3 Tahun 2020 tentang Pencegahan COVID-19 pada Satuan Pendidikan Nomor 36962/MPK.A/HK/2020 tentang pembelajaran daring. Program ini sangat cocok dilaksanakan di era penyebaran virus COVID-19 yang mana para dosen mensosialisasikan untuk melaksanakan physical dan social distancing (Handika dan Jeffry, 2020). Perguruan Tinggi yang ada di Kabupaten Jember telah mengeluarkan surat edaran resmi yang berisi pelaksanaan kuliah daring dilaksanakan mulai dari bulan Maret sampai Juni.

Kuliah daring sendiri dapat dipahami sebagai pendidikan formal yang diselenggarakan oleh Perguruan Tinggi yang peserta didiknya dan instrukturnya (dosen) berada di lokasi terpisah, sehingga memerlukan sistem telekomunikasi interaktif untuk menghubungkan keduanya dan berbagai sumber daya yang diperlukan di dalamya. Penerapannya dilakukan dengan cara penyampaian materi yang dilakukan melalui internet secara synchronous atau asynchronous. Hal ini memudahkan mahasiswa yang mengikuti program kuliah daring lebih menghemat waktu dan tenaga. Sehingga waktu dan tenaga yang tersisa dapat digunakan untuk hal-hal lainnya di luar jam perkuliahan. Persepsi tersebut mengarah pada model pembelajaran yang diperoleh dari beberapa pendekatan, media pembelajaran dalam perkuliahan daring, model komunikasi pembelajaran, gaya belajar, dan efektifitas perkuliahan daring.

Dengan adanya pembelajaran daring ini banyak hal yang harus dipersiapkan mulai dari sarana prasarana sampai kesiapan Perguruan Tinggi untuk proses pembelajaran yang pastinya mempunyai sistem berbeda di masing-masing kampus yang ada di Kabupaten Jember. Saat awal diberlakukannya perkuliahan daring setiap dosen memiliki strategi pem-belajaran berbeda-beda, mereka memiliki masing-masing cara untuk menyampaikan sebuah pembelajaran atau perkuliahan. Dalam proses pembelajaran, banyak sekali aplikasi yang digunakan diantaranya, Zoom, Google Classroom, Whatsapp Grup, LMS, Sister, Webex, dll. 
Sehingga para mahasiswa harus betul-betul menguasai pengoperasian media pembelajaran daring yang telah ditentukan. Pengetahuan terhadap media yang digunakan menentukan mahasiswa dalam dapat atau tidaknya mengoperasikan media pembelajaran. Ada beberapa dosen yang tanggap langsung memilih media pembelajaran seperti aplikasi Moodle, Google Classroom, Whatsapp, Telegram, E-learning masing-masing kampus dan lain-lain. Ada pula yang membutuhkan waktu hingga mahasiswa harus menunggu media pembelajaran yang tepat dari dosen untuk mahasiswa nya.

Dari berbagai macam media pembelajaran pada penelitian pada (Gambar 1) dihasilkan bahwa terdapat 46,9\% dari 50 mahasiswa yang tersebar di universitas dalam lingkup Kabupaten Jember memilih Whatsapp sebagai aplikasi paling efektif sebagai media pembelajaran dalam perkuliahan daring, selain itu 24,5\% memilih Google Classroom, 14,3\% memilih Zoom, Webex, ataupun Google Meet, 10,2 \% memilih E-learning , 4,1 \% menggunakan Edmodo, dan $0 \%$ menggunakan Telegram. Presentase 46,9\% menunjukkan banyaknya mahasiswa yang memilih menggunakan Whatsapp sebagai media pembelajaran paling efektif dibandingkan dengan aplikasi yang lainnya, hal ini dapat terjadi karena Whatsapp tidak hanya mudah untuk saling berkirim pesan dengan bentuk tulisan tetapi juga dalam bentuk foto, video ataupun audio, selain itu Whatsapp tidak membutuhkan banyak kuota internet untuk diakses di kalangan mahasiswa, sehingga lebih ringan dan lebih mudah, mengingat semua mahasiswa bahkan orang di dunia ini sudah memahami fitur - fitur dari Whatsapp karena banyak orang yang telah menggunakan aplikasi tersebut sebagai aplikasi keseharian dalam berkomunikasi secara virtual, Whatsapp sangat layak dimanfaatkan sebagai salah satu media dalam proses belajar mengajar, karena dapat mempermudah pembelajaran, membangkitkan motivasi, dan dapat meningkatkan keingintahuan dan sebagai sumber belajar mandiri (Aji, 2018). Sebanyak 24,5\% memilih menggunakan Google Classroom sebagai media pembelajaran paling efektif, hal ini menjadi alasan karena Google Classroom menyediakan fitur-fitur yang mudah dipahami dan sering digunakan oleh dosen-dosen diberbagai kampus, termasuk di Jember. Sebanyak 14,3\% telah memilih menggunakan video conference seperti Zoom, Webex, atau Google Meet dan lain-lain sebagai media pembelajaran yang efektif, karena kelebihan menggunakan media ini adalah mahasiswa dapat melakukan komunikasi secara langsung kepada dosen pengampu mata kuliah tersebut, akan tetapi untuk melakukannya mahasiswa harus menyediakan lumayan banyak kuota agar perkuliahan berjalan dengan lancar.

Bentuk teknologi informasi dan komunikasi dalam bidang pendidikan yang mampu mendigitalisasi-kan isi maupun sistem belajar mengajar konvensional yang dikenal sebagai Learning Management System atau yang lebih populer dengan sebutan LMS (Permana dan Wim, 2005). 
Menurut Susanti dan Sholeh (2008), sistem E-learning merupakan sistem pendidikan virtual berbasis web yang mempunyai tujuan utama untuk membantu proses kegiatan belajarmengajar. Seperti yang dijelaskan oleh Budi dan Nurjayanti (2012) juga bahwa pembelajaran tidak cukup hanya dengan pertemuan tatap muka saja, dengan adanya E-learning tenaga pengajar dapat meningkatkan intensitas komunikasi interaktif dengan mahasiswa di luar jam kuliah resmi. Bahan ajar yang diberikan dapat divisualisasikan sehingga memudahkan untuk mempelajarinya.

Learning Management System (LMS) atau SISTER merupakan bentuk E-learning yang sudah diterapkan di berbagai kampus yang mengacu kepada kemenristekdikti, sehingga Elearning menjadi media pembelajaran yang sudah disediakan kampus untuk mahasiswanya, sebanyak 10,2 \% memilih media pembelajaran yang dianggap efektif, karena E-learning mudah untuk dipahami mengenai fiturnya, hanya saja server akan sering eror karena banyak yang menggunakan ketika perkuliahan daring berlangsung. Selain E-learning Edmodo sebagai aplikasi pendidikan yang sering digunakan oleh tenaga pengajar termasuk dosen di berbagai kampus, sebanyak 4,2 \% mahasiswa di Jember memilih Edmodo sebagai media pembelajaran yang efektif, Edmodo memiliki fitur yang mudah dipahami oleh siapapun, kebebsan untuk ber interaksi menggunakan text sangat mudah dilakukan. Dan sebanyak 0\% mahasiswa memilih Telegram sebagai media pembelajaran efektif, $0 \%$ ini dikarenakan dosen di kampus lingkup Kabupaten Jember belum ada yang mengoperasikan Telegram sebagai media pembelajaran, karena fungsi dari Telegram kurang lebih sama dengan Whatsapp, sehingga lebih mudah diterapkan sebagai media pembelajaran selama perkuliahan daring berlangsung.

Perkuliahan daring menjadi sarana pembelajaran pengganti perkuliahan tatap muka, yang mana ketika pembelajaran tatap muka mahasiswa dapat berkomunikasi langsung dengan dosen pengampunya, begitupun dalam pembelajaran dalam perkuliahan daring. Proses pembelajaran dapat berlangsung dengan adanya media pembelajaran, sehingga mahasiswa dapat berkomunikasi secara virtual dengan dosen pengampunya. Interaksi belajar juga memegang peranan penting dalam proses belajar-mengajar ( $\mathrm{Su}$, et al., 2005), sehingga model komunikasi juga berdampak signifikan. Dalam pelaksanaan perkuliahan system virtual (Bentley, et al., 2012), ini diperlukan model komunikasi yang tepat. Jenis-jenis model komunikasi yang mungkin terjadi antara lain adalah komunikasi searah, komunikasi dua arah, dan komunikasi semi dua arah. Dari hasil angket pada penelitian pada (Gambar 2) ini sebanyak 70\% mahasiswa telah menggunakan komunikasi semi dua arah, 18\% menggunakan komunikasi dua arah, dan 12\% menggunakan komunikasi searah. Presentase $70 \%$ menunjukkan jenis komunikasi semi dua arah yang disukai oleh mahasiswa. 
Dalam komunikasi semi dua arah (Half Duplex) pengirim dan penerima informasi berkomunikasi secara bergantian namun tetap berkesinambungan. Contoh: Handy Talkie, FAX, dan Chat Room (Wikipedia, Indonesia), begitupun dalam proses pembelajaran perkuliahan daring antara mahasiswa dengan dosen, hal ini ditunjukkan dari banyaknya mahasiswa lebih menyukai penggunaan media chatroom yaitu Whatsapp lebih te-patnya Whatsapp Group yang memungkinkan adanya komunikasi secara bergantian antara dosen dan mahasiswa, dan tetap berkesinambungan sampai kapanpun. Sebanyak 18\% maha-siswa menyukai penggunaan jenis komunikasi dua arah, hal ini bisa ditunjukkan dengan adanya video conference seperti Zoom, Webex, Google Meeting, ataupun yang lainnya se-bagai media pembelajaran yang memungkinkan mahasiswa dan dosen berkomunikasi lang-sung secara virtual. Dan sebanyak $12 \%$ mahasiswa menyukai menggunakan jenis komunikasi searah, yaitu seperti pemberian power point, video, audio, maupun teks yang lain dari dosen, sehingga mahasiswa hanya menerima tanpa adanya feedback dari mahasiswa ke dosen pengampunya.

Selain jenis komunikasi pembelajaran dalam perkuliahan daring, gaya belajar merupakan salah satu pendukung dalam proses pembelajaran sebagai bentuk adaptasi mahasiswa dalam menghadapi strategi tertentu dalam perkuliahan daring. Menurut Darmadi (2017) menyebutkan bahwa secara realita jenis gaya belajar sesorang merupakan kombinasi dari beberapa gaya belajar yang terbagi menjadi tiga gaya belajar, yaitu : gaya belajar visual, gaya belajar auditori, dan gaya belajar kinestetik. Dan masing-masing mahasiswa mempunyai gaya belajar yang tidak sama tiap individunya yang akan mempengaruhi orang tersebut dalam memahami sesuatu (Manis dan Hoeda, 2010).

Berdasarkan angket survei online pada (Gambar 3) didapatkan hasil bahwa $64 \%$ mahasiswa menggunakan gaya belajar visual, $32 \%$ menggunakan gaya belajar auditori, dan $4 \%$ menggunakan kinestetik. Presentase $32 \%$ pada gaya belajar auditori menunjukkan bahwa mahasiswa Biologi di Kabupaten Jember lebih suka dengan gaya belajar yang bertumpu pada gambar yang melibatkan indera penglihatan yaitu berupa mata. Mahasiswa dengan gaya belajar visual lebih mudah untuk mengingat apa yang mereka lihat, misal seperti materi yang berbentuk gambar, video, diagram, dan lain-lain, selain itu bagi mahasiswa Biologi penjelasan materi tidak cukup jika hanya dengan metode ceramah yang mana mahasiswa hanya mendengarkan, akan lebih mudah paham jika materi disajikan dalam bentuk visual sedemikian rupa. Presentase $32 \%$ menunjukkan bahwa mahasiswa Biologi di lingkup Kabupaten Jember menyukai gaya belajar auditori, yaitu gaya belajar dengan cara mendengarkan sesuatu, seperti audio. Gaya belajar auditori ini memudahkan mahasiswa yang lebih suka mendengar daripada melihat, membaca, ataupun yang lainnya. 
Dan presentase $4 \%$ menunjuk-kan bahwa mahasiswa Biologi di lingkup Kabupaten Jember menyukai gaya belajar kines-tetik, yaitu gaya belajar dengan bergerak, mahasiswa yang demikian cenderung tidak bisa di-am, mereka merasa bisa memahami materi disertai dengan kegiatan fisik, misalkan hafalan sambil berolahraga, mempraktikkan apa yang telah dipelajari, karena mahasiswa dengan gaya belajar demikian memiliki rasa ingin tahu yang sangat tinggi, sehingga mereka perlu bergerak untuk mencarinya. Dari berbagai hal yang mendukung perkuliahan daring hingga membentuk suatu pemikiran yang menjadi pertanyaan mengenai penerapan perkuliahan daring dalam keefektifitas sebagai penunjang dari sebuah pembelajaran, khususnya di tingkat Perguruan Tinggi tak terkecuali bagi mahasiswa Biologi di Perguruan Tinggi Kabupaten Jember. Hasil dari penelitian pada (Gambar 4) dalam keefektifitas kuliah daring ini mahasiswa Biologi memilih sebanyak 40\% kurang puas, 32\% cukup puas, $8 \%$ tidak puas, $20 \%$ puas, $0 \%$ sangat puas. karena mahasiswa saat ini sudah banyak mengenal internet dan sudah masuk dalam masa era digital dimana pada era ini kita dapat mengakses informasi, dan bisa kapan saja un-tuk memulainya. Dengan situasi pandemi COVID-19 yang mengharuskan kita untuk tidak berkerumun, sehingga kuliah dilakukan secara online (daring). Sejalan dengan perkembangan era digital yang didukung oleh teknologi informasi dan komunikasi (TIK), maka pada saat pandemi ini era digital digunakan sebagai media pembelajran online. Pemanfaatna TIK dalam pembelajaran tidak hanya bersifat opsional, tetapi telah menjadi suatu keniscayaan. Keefek-tifan pembelajaran juga dipengaruhi oleh beberapa banyak dosen mampu memanfaatkan TIK. Sekarang ini, pedekatan konvensional telah banyak ditinggalkan dan beralih ke pembelajaran berbasis komputer atau biasa dikenal dengan pembelajaran daring (Thom, 2003; Beeain, 2004). Karena mahasiswa saat ini sudah pintar dalam menggunakan teknologi informasi dan komunikasi, kebanyakan mahasiswa merasa tidak keberatan dengan diadakannya perkuliahan daring ini. Namun keefektifan dalam melaksanakan perkuliahan daring ini beberapa maha-siswa merasa kurang puas bahkan cenderung tidak senang dengan pembelajaran. Ketidakpua-san tersebut terjadi karena adanya hambatan selama pelaksanaan oleh beberapa faktor. Ham-batan dalam pembelajaran sistem daring, mulai dari terbatasnya kuota, banyaknya tugas, pen-guasaan IT yang masih terbatas, jaringan yang tidak stabil karena kondisi responden yang ada di pedesaan, telat masuk kuliah karena tidak terbiasa menggunakan daring (Jamaluddin, dkk, 2020). Disisi lain pelaksanaan kuliah daring lebih santai, mahasiswa lebih aktif dalam pelaksanaan pembelajaran. Pembelajaran daring lebih efektif selama materi diberikan dengan proporsi yang pas dan tidak memberikan tugas yang berlebihan karena beban pembelajaran daring yang terlalu berlebihan juga berpotensi mengakibatkan stress pada mahasiswa. Dengan ini, pembelajaran akan efektif jika ditinjau dari model pembelajaran yang tepat melalui 
pendekatan penggunaan media pembelajaran, model komunikasi, gaya belajar. Penggunaan me-dia pembelajaran yang tepat untuk mengirim materi yang disampaikan baik berupa teks, dokumen, video, audio karena tidak semua materi pembelajaran dapat difahami dalam satu jenis metode pembelajaran saja. Hal ini berkaitan dengan gaya belajar mahasiswa yang berbeda tiap individunya, namun dengan penggunaan gaya belajar secara visual dapat memudahkan mahasiswa memahami materi yang diajarkan. Serta penggunaan model komunikasi semi dua arah yang membuat pembelajaran seperti diskusi lebih hidup, karena mahasiswa dan dosen dapat berinteraksi memberi umpan balik.

\section{KESIMPULAN DAN SARAN}

\section{Kesimpulan}

Dari hasil pengolahan data menunjukkan bahwa 50 orang mahasiswa Biologi di Perguruan Tinggi Kabupaten Jember menilai keefektifan pembelajaran daring ditinjau dari model komunikasi dengan pendekatan penggunaan media belajar, mahasiswa lebih memilih aplikasi Whatsapp yang dianggap paling efektif karena sudah digunakan dalam kehidupan sehari-hari sehingga mudah dalam pengoperasiannya. Dan media komunikasi yang sering digunakan komunikasi semi dua arah. Mahasiswa Biologi lebih menyukai gaya belajar visual yang mana biasanya dalam bentuk gambar, power point, video, dll karena metode ceramah saja tidak cukup dalam pembelajaran. Efektifitas pembelajaran dirasa kurang puas karena bergantung pada kemampuan dan motivasi belajar. Namun dengan menggunakan model pembelajaran seperti pemilihan media pembelajaran, model komunikasi dan gaya belajar yang tepat mengarahkan pada kesuksesan pembelajaran daring.

\section{Saran}

Dengan mengetahui preferensi mahasiswa, para dosen atau tenaga pengajar dapat menyiapkan pembelajaran dalam perkuliahan daring sedemikian rupa mulai dari media pembelajaran dalam perkuliahan daring, model komunikasi pembelajaran, gaya belajar, dan keefektifan perkuliahan daring yang sesuai dengan apa yang diharapkan mahasiswa, hingga tercapainya tujuan dari suatu pembelajaran. Dan dengan ini diharapkan secara tidak langsung juga dapat meningkatkan semangat dalam belajar serta pencapaian dari mahasiswa tersebut. Selain itu, diperlukan adanya penelitian lebih lanjut terhadap penelitian pembelajaran daring yang lebih menarik dan efektif untuk mahasiswa Biologi khususnya. 


\section{DAFTAR RUJUKAN}

Aji, S. H. (2018). Pengembangan Aplikasi Layanan Pesan Instan Whatsapp Sebagai Sumber Belajar Mandiri untuk Meningkatkan Motivasi dan Hasil Belajar Fisika Materi Pokok Efek Rumah Kaca Peserta Didik Kelas XI SMAN 1 Purwokerto. (Intergovernmental Panel on Climate Change, Ed.), Univesitas Negeri Yogyakarta. Universitas Negeri Yogyakarta, Yogyakarta. https://doi.org/10.1017/CBO9 781107415324.004

Bentley, Y., Selassie, H., \& Shegunshi, A. (2012).Design and evaluation of student-focused eLearning. Electronic Journal of E-Learning, 10(1), 1-12. https://doi.org/10.1007/s10648013-9243-1

Budi dan Nurjayanti, B. 2012.Pengembangan Metode Pembelajaran Berbasis Online ELearning (Studi Kasus Mata Kuliah Bahasa Pemrograman).Jurnal Sains Terapan, Vol. 2, No.1.

Darmadi, 2017. Pengembangan Model Dan Mertode Pembelajaran Dalam Dinamika Belajar Siswa. Yogyakarta: DeepPublish.

Handika, Jeffry, dkk. 2020. Pembelajaran Sains di Era Akselerasi Digital. CV. AE MEDIA GRAFIKA

Jamaludin, Dindin, dkk. 2020. Pembelajaran Daring Masa Pandemi Covid-19 Pada Calon Guru : Hambatan, Solusi dan Proyeksi. Karya Tulis Ilmiah, Lembaga Penelitian Dan Pengabdian Kepada Masyarakat UIN Sunan Gunung Djati Bandung.

Kemendikbud, 2020. Pusat Pendidikan dan Pelatihan Pegawai Kementrian Pendidikan dan Kebudayaan.https://pusdiklat.kemdikbud.go.id/surat-edaran-mendikbud-no-4tahun-2020-tentang-pelaksanaan-kebijakan-pendidikan-dalam-masa-daruratpenyebaran-corona-virus-disease-covid-1-9/

Kuntarto, E. \& Asyhar, R. (2017). Pengembangan Model Pembelajaran Blended Learning Pada Aspek Learning Design dengan Platform Media Sosial Online Sebagai Pendukung Perkuliahan Mahasiswa. Repository Unja. Https://repository.unja.ac.id/cgi/users/home?screen=EPrint::View\&eprintid=626

Manis, Hoeda . 2010. Learning is easy. Kelompok Gramedia.

Mulyaningsih, I, Nurfiana, N, \& Zahidin, M. A. 2017. Pengembanagan Pembelajaran Berbasis riet Di jurusan Tadris Bahasa Indonesia FTIK, IAIN Syekh Nurjati Cirebon. Jurnal Indonesian Language Education and Literature, Vol. 2 ,No. 2.

Permana, Wim. 2005. Pemanfaatan e-learning sebagai Pendukung Kegiatan Belajar Mengajar Universitas Terbuka di Indonesia: Studi Perangkat Lunak. Program Studi Ilmu Komputer, FMIPA, UGM, Yogyakarta. 
Su, B., Bonk, C. J., Magjuka, R. J., Liu, X., \& Lee, S. (2005). The importance of interaction in web-based education: A program-level case study of online MBA courses. Journal of Interactive Online Learning, 4(1), 1-19. https://doi.org/ISSN1541-4914

Susanti, E. dan Sholeh, M. 2008. Rancang Bangun Aplikasi e-learning. Jurnal Teknologi, Vol. 1, No. 1

Thorne, K,. 2003. Blanded Learning : How to Integrate Online \& Traditional Learning. London \& Sterling, VA : Kogan Pge Limited.

Wikipedia, 2020.Wikipedia, Indonesia. https://id.wikipedia.org/wiki/Telekomunikasi 